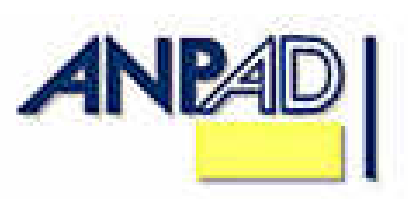

Available online at

http://www.anpad.org.br/bar

\title{
The Learning Process in Interorganizational Relationships
}

\author{
Vania de Fátima Barros Estivalete * \\ E-mail address: vaniafbe@ terra.com.br \\ Universidade Federal de Santa Maria \\ Santa Maria, RS, Brazil.

\section{Eugenio Avila Pedrozo} \\ E-mail address: eapedrozo@ea.ufrgs.br \\ Universidade Federal do Rio Grande do Sul \\ Porto Alegre, RS, Brazil.
}

\section{Luciano Barin Cruz}

E-mail address: 1barincruz@unifor.br

Universidade de Fortaleza

Fortaleza, CE, Brazil.

\begin{abstract}
This study was inspired by the proposition developed by Karthik (2002) and applied to a context of horizontal interorganizational relations. Our main objective was to understand how the learning process between organizations inserted in networks occurs, from the perspective of the evolution of relationships over time. This study has a qualitative and exploratory nature, and the method adopted is the case study with multiple units of analysis. The research was carried out in a network of thirteen supermarket companies in the State of Rio Grande do Sul, Brazil. The data was collected through individual interviews, questionnaires, documental sources and histories of learning. As the main contribution, we highlight the critical discussion made of the model proposed by Karthik (2002) as it is applied in horizontal networks: contradicting the author's suggestion, the results of this research reveal that there was a predominance of mutual learning in the initial stages of the companies' relationships and, as the relationships evolved, there was a predominance of unilateral learning. This change can be seen in the adoption of opportunist behavior and the predominance of structural characteristics of trust in the relationships established by the companies involved.
\end{abstract}

Key words: learning process; interorganizational relationships; networks.

Received 12 March 2008; received in revised form 19 July 2008.

Copyright (C) 2008 Brazilian Administration Review. All rights reserved, including rights for translation. Parts of this work may be quoted without prior knowledge on the condition that the source is identified.

\footnotetext{
* Corresponding author: Vania de Fátima Barros Estivalete

Universidade Federal de Santa Maria, Rua Floriano Peixoto, 1184, 5º andar, Santa Maria, RS, 97015-372, Brazil.
} 


\section{INTRODUCTION}

The complex environment in which organizations must operate demands new management techniques. To work not only competitively but also cooperatively is the great strategic challenge for companies. In this context, the cooperation strategy has recently been gaining much more attention in the academic literature and in managerial decisions. From this perspective, the interorganizational learning process can be seen as a managerial instrument to induce organizations to create appropriate structures and strategies for facing this complex environment.

New interorganizational arrangements such as company networks (the focus of this study) can be considered a platform for interorganizational learning, as they provide the organizations with access to knowledge from partner companies (Inkpen, 2000). However, it is necessary to note that interorganizational relationships evolve over time; organizational competences change and objectives are redefined and, consequently, the learning dynamics and the interactions between partner companies also change (Karthik, 2002). Therefore, discussions of how learning occurs from the evolutionary perspective of interorganizational relationships can provide a contribution to the companies individually and collectively or to the network as a whole.

Karthik (2002) details an exploratory framework, aiming to understand the evolutionary perspective of learning focused on the study of strategic alliances. Thus, inspired by the studies developed by Karthik (2002) and applying the discussion of the same theme to the context of horizontal interorganizational relationships, this article seeks to understand how the learning process between organizations inserted in networks occurs from the perspective of the evolution of relationships through time. As our main contribution, we highlight the critical discussion of the model proposed by Karthik (2002) as it is applied in horizontal networks: contradicting the author's suggestion, the results in this research reveal that there was a predominance of mutual learning in the initial stages of the companies' relationships and, as the relationships evolved, that there was a predominance of unilateral learning. In an attempt to achieve the objectives proposed, research of an exploratory nature was carried out.

This research is organized as follows: the next section presents the theoretical foundations that guided the development of this work, approaching the learning process in an interorganizational context and advancing an analysis from the perspective of relationship evolution; after that, we present the research methodology used in this study; later, the results of the research are described; and finally, we present the final conclusions, suggestions for future research, limitations and basic references of the theoretical discussion.

\section{INTERORGANIZATIONAL LEARNING: AN ANALYSIS FROM THE PERSPECTIVE OF RELATIONSHIP EVOLUTION}

Academia has dedicated special attention to the concerns of organizational learning. There is a vast amount of literature characterizing the fragmentation of definitions and concepts concerning this theme. Prange (1999, p. 42) strengthens this understanding by mentioning that the "multiplicity of ways in which the organizational learning has been classified and used has the sense of a 'jungle of organizational learning' that is becoming dense and impenetrable".

However, it is worth mentioning some of the world-renowned researchers who study organizational learning and have contributed significantly to the advances in this field of knowledge (Antonacopoulou, 1999; Argyris \& Schön, 1978; Child \& Faulkner, 1998; Easterby-Smith, Araujo, \& Burgoyne, 1999; Fiol \& Lyles, 1985; Senge, 1990; Sweringa \& Wierdsma, 1995; among others). 
After examining these definitions of organizational learning and considering the cooperative relationships that are arranged in the business world, we opted to extend the discussion of the learning theme to the interorganizational level. Learning through interorganizational relations can be considered an emergent theme in the academic field and also in the business environment.

Knight (2002) agrees with this line of thought when he states that the concepts of individual, group and organizational learning have been established for a long time, therefore making it necessary to consider learning at a fourth level of analysis, which is interorganizational learning. This author shares the understanding that if, by interacting, a group of companies alter the behavior or the cognitive structures of the group, then the group of companies is learning and not only the organizations individually.

Following the same line of thought, Larsson, Bengtsson, Henriksson and Sparks (1998) differentiates organizational learning from interorganizational learning by noting that interorganizational learning includes synergy and the effects of interactions between organizations that would not exist were there no interaction among them. The same authors are of the opinion that interorganizational learning is one of the motivators for the formation of strategic alliances, although they acknowledge that the process of development of collective knowledge may be hindered by managerial problems.

We can add Cohen and Levinthal's (1990) contributions to organizational learning by including the role of absorptive capacity in the learning process. To Cohen and Levinthal (1990, p. 128), absorptive capacity is "companies' ability to recognize the value of new knowledge, assimilate and apply the knowledge for commercial ends". In this sense, to recognize, assimilate and apply the knowledge that is being developed by organizations requires active engagement of the actors involved, as well as the building of a trustful environment seeking to strengthen the relationships established.

In accordance with these approaches, Karthik (2002) (although considering learning as a primary motivation for the formation of strategic alliances) states that as time passes, alliances evolve and there is a metamorphosis in the way the partners involved in cooperative relations learn. The article by Karthik (2002) was the great motivator for the undertaking of the research for this study, since it deals with the mechanisms and processes that contribute to the learning process throughout the evolutionary phases of interorganizational relationships such as strategic alliances.

Karthik (2002) centers his studies in four distinct evolutionary phases through which strategic alliances progress: (1) awareness and partner selection; (2) exploration; (3) expansion; and (4) commitment to relationship. According to this author, the partnerships established change through time and, consequently, the dynamics of learning and the interactions between those involved also evolve. Thus, the partners use several mechanisms regarding the individual (unilateral) and mutual learning processes, which are revealed in the several phases that compose the evolutionary process of interorganizational relationships.

Based on this perspective, Karthik (2002) presents (as shown in Table 1) the evolutionary phases of strategic alliances, emphasizing the importance of understanding how the dynamics of learning occur throughout these phases. To develop his research, Karthik used contributions from Doz and Hamel (1998) when considering the five key areas that allow the investigation of learning processes and mechanisms: environment, tasks, processes, abilities and goals. 
Table 1: Learning Priorities in Alliance Evolution

\begin{tabular}{|c|c|c|c|c|}
\hline \multirow{2}{*}{$\begin{array}{l}\text { Learning } \\
\text { Dimensions: }\end{array}$} & \multicolumn{4}{|c|}{ Phases of Evolution } \\
\hline & $\begin{array}{l}\text { Phase I } \\
\text { Awareness and } \\
\text { Partner Selection }\end{array}$ & $\begin{array}{l}\text { Phase II } \\
\text { Exploration }\end{array}$ & $\begin{array}{l}\text { Phase III } \\
\text { Expansion }\end{array}$ & $\begin{array}{l}\text { Phase IV } \\
\text { Commitment to } \\
\text { Relationship }\end{array}$ \\
\hline Environment & $\begin{array}{l}\text { External context, } \\
\text { including cultural, } \\
\text { national context. }\end{array}$ & $\begin{array}{l}\text { External context. } \\
\text { Internal: partner } \\
\text { corporate culture, } \\
\text { management practices. }\end{array}$ & $\begin{array}{l}\text { External context, for } \\
\text { new opportunities. }\end{array}$ & $\begin{array}{l}\text { External context, mutually, } \\
\text { for new opportunities. }\end{array}$ \\
\hline Skill & $\begin{array}{l}\text { Explicit knowledge } \\
\text { about potential } \\
\text { partner skills. }\end{array}$ & $\begin{array}{l}\text { Initiation of transfer of } \\
\text { implicit skill knowledge } \\
\text { later in the phase. }\end{array}$ & $\begin{array}{l}\text { Transfer of implicit } \\
\text { skill knowledge. }\end{array}$ & $\begin{array}{l}\text { New skill development and } \\
\text { acquisition for mutual benefit. }\end{array}$ \\
\hline Goals & $\begin{array}{l}\text { Strategic intentions } \\
\text { and initial goals of } \\
\text { potential partners. }\end{array}$ & $\begin{array}{l}\text { Partner goals, to seek } \\
\text { compatible goals and } \\
\text { establish common } \\
\text { goals. }\end{array}$ & $\begin{array}{l}\text { Learning to set } \\
\text { alliance goals that } \\
\text { benefit partners. }\end{array}$ & $\begin{array}{l}\text { Ability to evaluate and revise } \\
\text { alliance goals continuously to } \\
\text { sustain advantage. }\end{array}$ \\
\hline Task & Very little. & $\begin{array}{l}\text { Initiation of } \\
\text { understanding and } \\
\text { establishing common } \\
\text { alliance tasks. }\end{array}$ & $\begin{array}{l}\text { Ability to establish } \\
\text { common partnership } \\
\text { tasks. }\end{array}$ & $\begin{array}{l}\text { Ability to revise and reset } \\
\text { effective alliance tasks. }\end{array}$ \\
\hline \multirow[t]{2}{*}{ Process } & Very little. & $\begin{array}{l}\text { Initiation of the } \\
\text { streamlining of } \\
\text { processes to perform } \\
\text { alliance tasks. }\end{array}$ & $\begin{array}{l}\text { Ability to establish } \\
\text { joint alliance } \\
\text { processes for mutual } \\
\text { benefit. }\end{array}$ & $\begin{array}{l}\text { Learning to revise and reset } \\
\text { joint processes for best } \\
\text { efficiency and effectiveness. }\end{array}$ \\
\hline & Unilateral Learning. & $\begin{array}{l}\text { Mostly Unilateral. } \\
\text { Elements of Mutual } \\
\text { Learning. }\end{array}$ & $\begin{array}{l}\text { Both Unilateral and } \\
\text { Mutual Learning. }\end{array}$ & Predominantly Mutual. \\
\hline
\end{tabular}

Source: Karthik (2002, p. 4).

The proposition developed by Karthik (2002) considers that the alliances or established relationships progress from phase I - awareness and partner selection - to phase IV commitment, while the priorities of learning change in accordance with this evolution. According to Karthik (2002), the characteristics of each phase are present in sequence, and the learning processes are presented from an evolutionary perspective of relationships.

In the initial phase of Awareness and Partner Selection, there is recognition that a partnership is essential for obtaining a competitive advantage. The companies involved expend considerable effort in determining whether they are compatible for sharing resources and building capacities in the exploration of new business opportunities (Karthik, 2002). In Karthik's (2002) view, learning begins in this stage but is generally unilateral. The organizations start to learn about the strategic intentions, abilities and competences that the potential partners possess.

In the following phase, called Exploration, the partners start to interact and prepare themselves to establish long term relationships through the definitions of rules and norms that will serve as a guide for future relations. In this phase, the learning is still to a great extent unilateral; however, elements of mutual learning begin to emerge (Karthik, 2002). According to Karthik (2002), the internal environment becomes an important area for the accomplishment of goals, and mutual learning begins as a way of minimizing the gap of compatibility between the partners involved.

Phases III and IV - Expansion and Commitment to Relationship - exhibit many common characteristics. To Karthik (2002), these phases are characterized by high interdependency, greater trust and an increase in investments for mutual benefit. In these two phases, there is high awareness of the congruent goals and cooperation of those involved. Unilateral learning leads the way to mutual 
learning through collective efforts focused on the development and acquisition of new abilities for the alliance (Karthik, 2002).

The contributions pointed out by Karthik (2002) allow new possibilities for research since they permit a better understanding of how learning efforts emerge between organizations in an alliance through an evolutionary perspective, keeping in mind the several phases involved in this evolutionary process. In the face of this, the role of trust is essential for the interorganizational learning process, if we consider that it influences the magnitude and efficiency of the knowledge shared between the actors involved (Lane, Salk, \& Lyles, 2001).

One of the studies of note dealing with trust in interorganizational relationships is that of Larsson et al. (1998), which mentions two dimensions involved in this concept. The first dimension is called structural and refers to calculative trust, which, according to Larsson et al. (1998), is based on mutual assistance between partners, the reputation involved and the motivation to establish cooperative relations in order to add value through the complementarity of resources. The second dimension is behavioral, based on the belief that organizations that establish interorganizational relationships will avoid the adoption of opportunist behaviors, engaging in positive and well-intentioned interactions with the partner companies.

The theoretical propositions discussed above have enabled the development of a framework to analyze and better understand how the learning process occurs from the perspective of the evolution of interorganizational relationships, as can be seen in Figure 1. In this sense, the analytical framework used in this research was formed from a combination of different elements, inspired by the studies of Karthik (2002) and Larsson et al. (1998). The phases of evolution of the interorganizational relationships, the different phases of the learning process (Karthik, 2002) and the role and the dimensions of trust (Child, 1999; Lane et al., 2001; Larsson et al., 1998) are essential elements for the analysis of how the learning process occurs among organizations that establish business relations from the perspective of the evolution of relationships.

Figure 1: Analytical Framework for Learning from the Perspective of the Evolution of Relationships

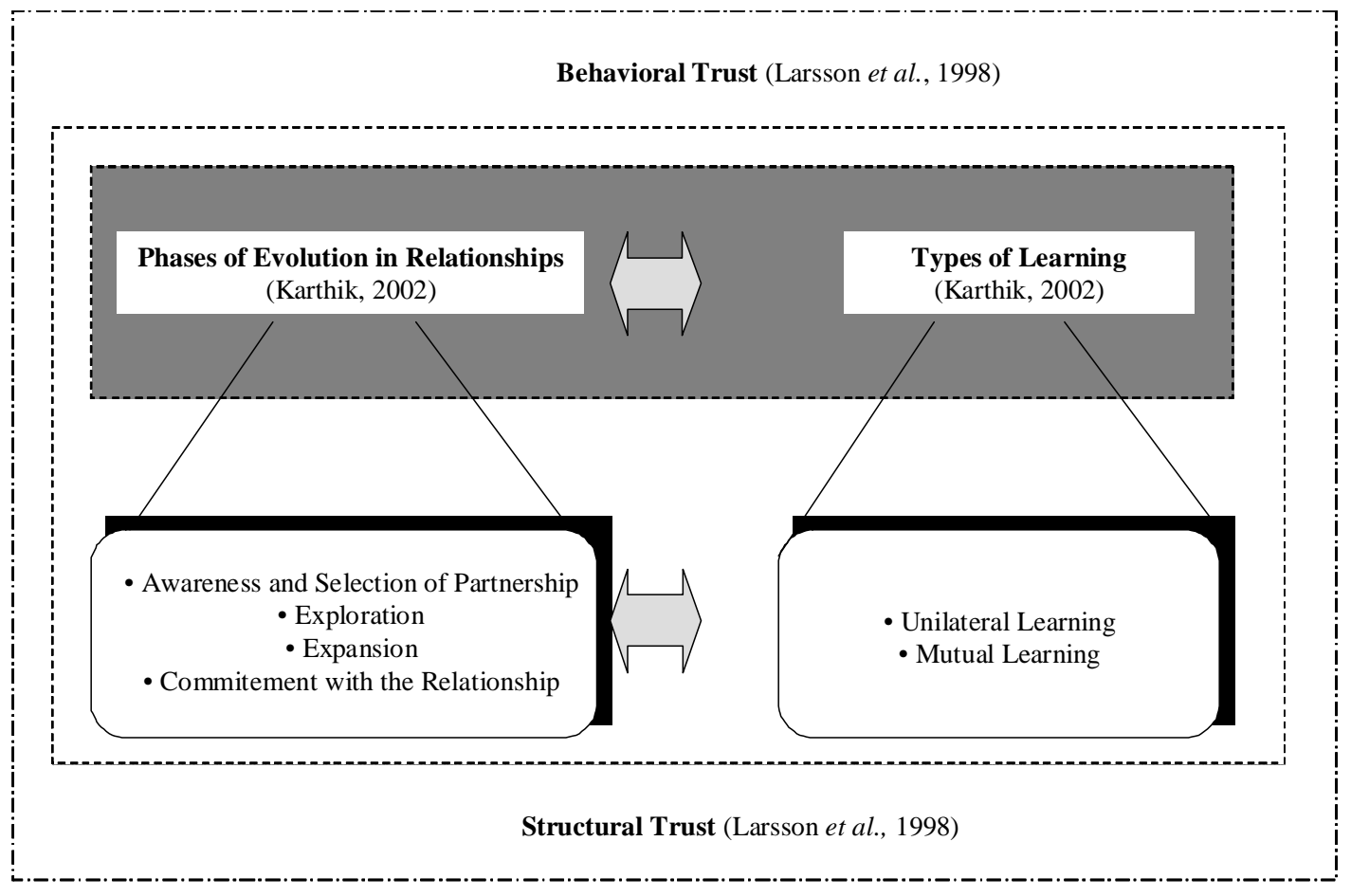

Source: prepared by the authors based on Karthik (2002, p. 2-4); Larsson et al. (1998, p. 295). 
This combination, involving the dynamics of learning from a perspective of evolution and the role of trust has stimulated research on and analysis of these constructs from the perspective of interorganizational relationships in horizontal networks.

\section{METHODOLOGY}

Inspired by the research developed by Karthik (2002), a study of a qualitative and exploratory nature was carried out, using the case study as the research method (according to Yin, 2002). As suggested by Siggelkow (2007) and Eisenhardt and Graebner (2007), we have developed this study in a persuasive way. The case study detailed in this research serves as a source of inspiration and illustration, as suggested by Siggelkow (2007). It functions as inspiration because it applies the model proposed by Karthik (2002) to one possible new theoretical discussion for the field. As an illustration, this model is applied to the example of a Brazilian supermarket network. For better comprehension, Figure 2 presents a summary of the steps involved in the research.

The research was carried out in a supermarket network located in the State of Rio Grande do Sul, Brazil, composed of thirteen supermarket businesses that establish horizontal interorganizational relationships and are part of the retail link of the agribusiness sector. The organizations that are part of the network have been establishing relationships since 1997 due to initiatives of the proprietors/associates. We note that, in Brazil, there are a significant number of networks that are established by entrepreneurship initiatives and by public institutions.

\section{Figure 2: Steps Involved in the Research}

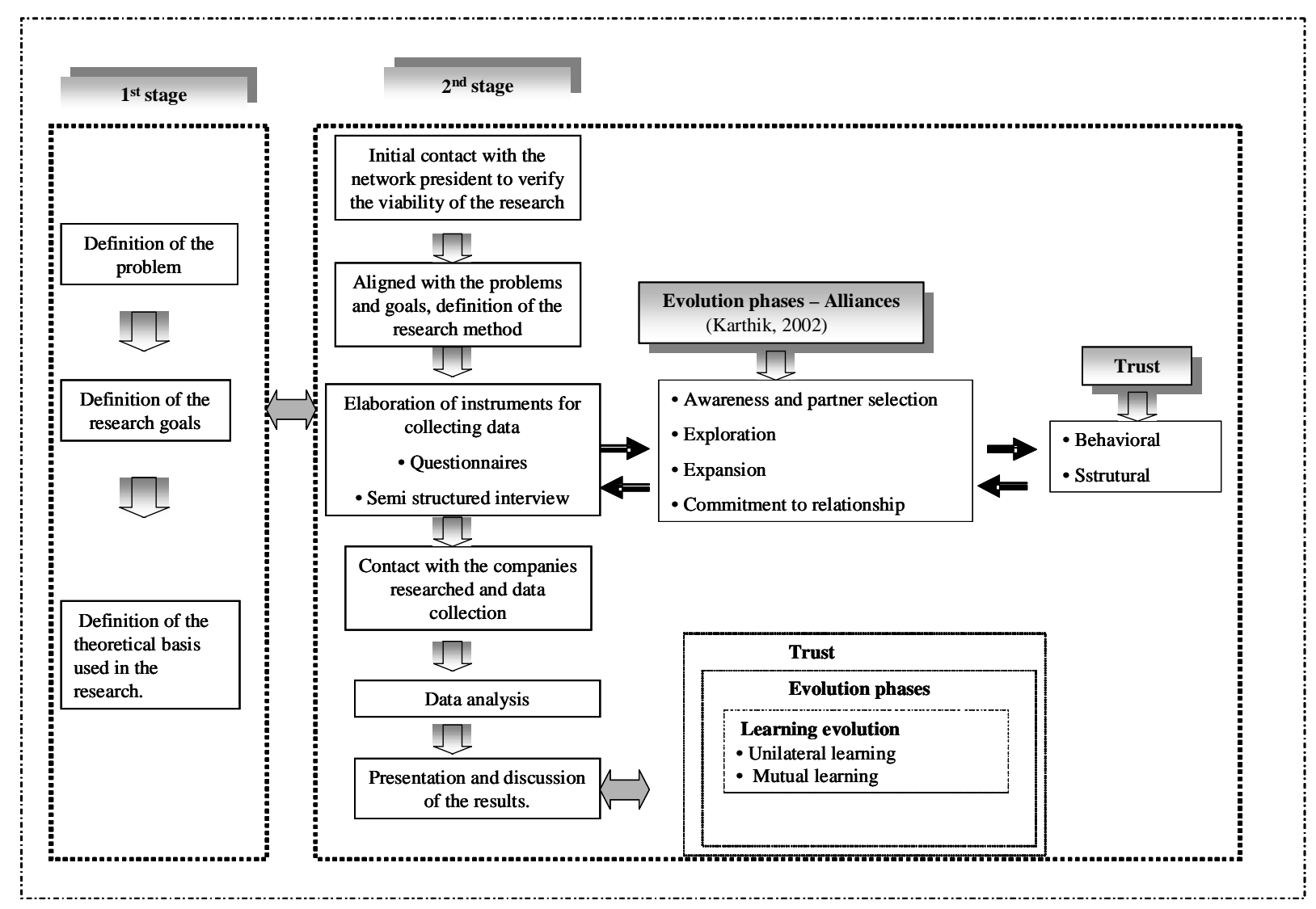

Source: prepared by the authors. 
Thirteen managers of the companies that make up the network were interviewed, including the current president of the network. The profile of the people interviewed presents the following characteristics: $69 \%$ are over 30 years of age, and 31\% are under 30; 92\% of the subjects are men, which means that only one woman was part of the research; $47 \%$ have completed higher education, $15 \%$ have incomplete higher education, $15 \%$ have completed high school, and $23 \%$ have only completed elementary school; the majority (54\%) have more than 10 years of employment experience with their respective companies, $31 \%$ have 5 to 10 years of experience and only $15 \%$ of the subjects have less than five years' experience in the company. Five companies have been part of the network since its inception, one company has been a member for five years, five companies joined approximately two years ago and two companies became part of the network only one year ago.

The techniques used for data collection were: semi-structured individual interviews, questionnaires, document sources and learning histories. To identify elements of learning throughout the four phases in the evolution of relationships proposed by Karthik (2002), individual in-depth interviews were carried out and we collected reports of learning histories from the interviewees.

In this study, we have followed the data triangulation technique using transcripts of the interviews, the documents collected and the observations made within the organizations studied.

The following analytical categories emerged from the data analysis: phases of evolution of interorganizational relationships and the dynamics of learning during this evolution.

\section{RESULTS}

The work developed by Karthik (2002) was used for analyzing the data, focusing on the four evolutionary phases through which interorganizational relationships progress over time. It is interesting to highlight that the analysis of the results was carried out by generally considering the four phases proposed by Karthik (2002), but without dismembering the data in the five key areas developed by Doz and Hamel (1998), due to the fact that this division was not suitable for our case.

\section{Awareness and Partner Selection}

According to the opinions of those interviewed, in the phase of awareness and partner selection, processes of mutual learning emerged through the need for greater socialization, information sharing and the execution of joint investments between the organizations in the network. Evidence for this can be seen in quotes from some of the interviewees:

"At the initial meetings of the network, the information was passed on in a clear and transparent way" [Manager of Company 7].

"When the network was created, each actor brought their prior experiences [...] what they had done in a crisis situation" [Manager of Company 3].

"Before the beginning of the network we didn't care for the other actors [...] since the network's creation, we have started to collaborate, to learn together" [Manager of Company 2].

In this phase, unlike from Karthik's (2002) proposal, greater interdependence between the companies was found, along with greater engagement of the partners that compose the network. It can be deduced that such attitudes derive from the initial stage in which the network was situated, which demanded greater interaction and knowledge sharing among those involved. 


\section{Exploration}

As time passed, in the exploration phase, elements of mutual learning were also identified, mainly because of the systematic efforts among the partner organizations to acquire abilities that enable the enhancement of absorptive capacity which, according to Cohen and Levinthal (1990, p. 128), consists of the "companies' ability to recognize the value of external knowledge, assimilate it and apply it for commercial means". In Karthik's (2002) view, this phase of learning is still very unilateral, with few initiatives in terms of mutual learning. However, the results reveal that there was a predominance of mutual learning among the companies in the researched network, perhaps because of the emerging needs for transference and acquisition of knowledge and abilities, and because of interest in the development of group initiatives to obtain mutual benefits for the partner companies.

This result can be seen in some of the interviewees' remarks.

"I learned more after I entered the network. Every time I went to the conferences [...] I learned about client relations and price. Before that, I just cared about price [...] but if you don't have a good seller, you can't sell the product" [Manager of Company 2].

"As time has passed we have learned to cooperate, to share knowledge and experiences. We have learned to be partners" [Manager of Company 6].

"After we met our partners, we started to be much more open to knowledge, to forget the fights" [Manager of Company 5].

"The network brings benefits to everybody [...] it gives us buying power [...] the power of knowing how our partners act [...] it has helped us to find easier solutions" [Manager of Company 7].

\section{Expansion}

In the phase of expansion, the managers perceived the predominance of unilateral learning elements that manifested themselves through the adoption of opportunist initiatives by some of the partners. This resulted in contractual breaches or alterations meant to benefit some organizations involved in the network. Some evidence can be seen in the remarks of the interviewees:

"The network was growing and the biggest companies started to have more power. [...] they have started to act for their own benefit [...] individually" [Manager of Company 1].

"In the beginning, the partners shared more knowledge [...] nowadays, we distrust each other" [Manager of Company 6].

"Over time, some conflicts have broken out among the network players [...] a way to work has been defined, but some people don't follow it" [Manager of Company 7].

"In the beginning, knowledge flowed better in the network [...] at that time, it seems that the individualistic vision became dominant [...] the players don't want to share knowledge any more" [Manager of Company 4].

In this stage of evolution, according to Karthik (2002), unilateral learning should lead the way to mutual learning. This was not the case in this research, probably because of the predominance of the structural dimension of trust over the behavioral dimension. According to Larsson et al.'s (1998) line of thought, the structural dimension of trust is based on the rational motivation to participate in cooperative relations to aggregate value through resources, mutual help and reputation. The behavioral dimension, however, is based on well-intentioned beliefs and optimistic expectations that the companies establishing interorganizational relationships will execute positive actions, thereby avoiding negative actions and opportunistic initiatives (Child, 1999; Larsson et al., 1998).

It is worth mentioning Child's (1999) understanding of calculative trust (structural) as an important element in new relations and in the phase of alliance formation. In this respect, this study revealed a 
certain paradox, because in the phase of expansion, the degree of trust should have elevated to the cognitive and/or behavioral level (Pereira, 2005). Maybe this happens because the majority of organizations that compose the analyzed network had joined it after the formation of the network, with only five of the thirteen companies establishing cooperative relationships since the phase of formation.

\section{Commitment to Relationship}

In the phase of Commitment to Relationship, elements of mutual learning and unilateral learning were identified among the companies involved. Mutual learning manifested itself among the organizations that were part of the network for a longer period of time in proportion to their size. In the medium-sized organizations, the relations of mutual interdependence were clearer and more evident than in the smaller companies, which manifested feeling damaged by the collective decisions made by the partners.

These results are corroborated by some interviewees' remarks:

"One of the negative points of the network is that the companies are not all the same size. The larger companies learn more and they can have more advantages over the smaller ones" [Manager of Company 1].

"The right thing would be for everyone in the network to pass along knowledge [...] sometimes I perceive that the largest companies don't want to share their knowledge and experience [...]so, I go to the other stores and I see what could I do in my store" [Manager of Company 2].

"The network was created to compete with the 'BIG NETWORK', to have more power [...]It was created to make the small companies stronger and give them greater bargaining power [...] in the beginning it generated some results, but now [...] not any more" [Manager of Company 4].

"My company is small, and I did not feel good when they changed the internal workings to give some advantages to the biggest companies [...] this is wrong" [Manager of Company 10].

To Karthik (2002), the 'commitment to relationship' phase should be characterized by high interdependence and by the existence of high levels of investment and greater trust between those involved so that mutual learning can truly be rendered concrete. Based on this line of thought, it is interesting to emphasize the need for greater comprehension of the intertwining of the trust element with the interorganizational learning process. The interviewees agree that the greater the trust between partner organizations, the smaller the probability of the actors involved adopting opportunist behaviors to gain individual advantages. However, as the structural dimension of trust is prevailing over the behavioral dimension in this situation, this research strongly shows that to the investigated organizations it is highly important to seek initiatives that lead to the strengthening of the behavioral dimension. This could facilitate the mutual learning process between network partners since the relationships evolve over time.

To facilitate the visualization of the results, we present them succinctly in the following table. 
Table 2: The Evolutionary Phases and the Learning Process (Based on Karthik, 2002)

\begin{tabular}{|l|l|l|l|l|}
\hline Phases & $\begin{array}{l}\text { Awareness and } \\
\text { partner selection }\end{array}$ & Exploration & Expansion & $\begin{array}{l}\text { Commitment to } \\
\text { Relationship }\end{array}$ \\
\hline Characteristics & $\begin{array}{l}\text { Greater socialization } \\
\text { Information exchange } \\
\text { Joint investments }\end{array}$ & $\begin{array}{l}\text { Acquisition of abilities } \\
\text { Better absorptive capacity } \\
\text { Transference and } \\
\text { acquisition of knowledge }\end{array}$ & $\begin{array}{l}\text { Adoption of opportunist } \\
\text { initiatives } \\
\text { Contractual breaches } \\
\text { or alterations } \\
\text { Predominance of } \\
\text { structural trust } \\
\text { characteristics }\end{array}$ & $\begin{array}{l}\text { More relationship time } \\
\rightarrow \text { mutual learning, } \\
\text { Medium-sized } \\
\text { companies } \begin{array}{l}\rightarrow \\
\text { interdependence } \\
\text { relationships } \\
\text { Small-sized companies } \\
\text { clamaged because of } \\
\text { the decisions }\end{array}\end{array}$ \\
\hline Learning & Mutual learning & Mutual learning & Unilateral learning & $\begin{array}{l}\text { Mutual and unilateral } \\
\text { learning }\end{array}$ \\
\hline
\end{tabular}

Source: prepared by the authors, based on research data.

Analyzing the evolution of the learning process among organizations that establish horizontal network relationships throughout the four phases contemplated in the model proposed by Karthik (2002), we notice a certain paradox, since learning should evolve from a stage of unilateral learning to one of mutual learning. However, the results reveal that in the initial phase of the relationship between the partner companies, there was a predominance of mutual learning that was exemplified by the exchange of knowledge, greater interdependence and greater engagement of the managers in search of new opportunities and a greater level of behavioral trust among the actors involved. When the relationships progressed in time, we found a predominance of unilateral learning that was embodied by the adoption of opportunist behaviors and the predominance of structural characteristics of trust in the relationships established among partner companies. It is interesting to add that the studies developed by Karthik (2002) were carried out in strategic alliances, and that in the present research, the focus of investigation is on organizations that establish horizontal network relationships. Therefore, we can infer that there is an inversion in the relevant learning elements when considering horizontal network relationships in the light of the research conducted with strategic alliances.

In Figure 3 we visualize the relations between the relationship phase, learning type and trust type, considering the evolution of relationships over time. 
Figure 3: Relation between the Relationship Phase, the Learning Type and the Trust Type

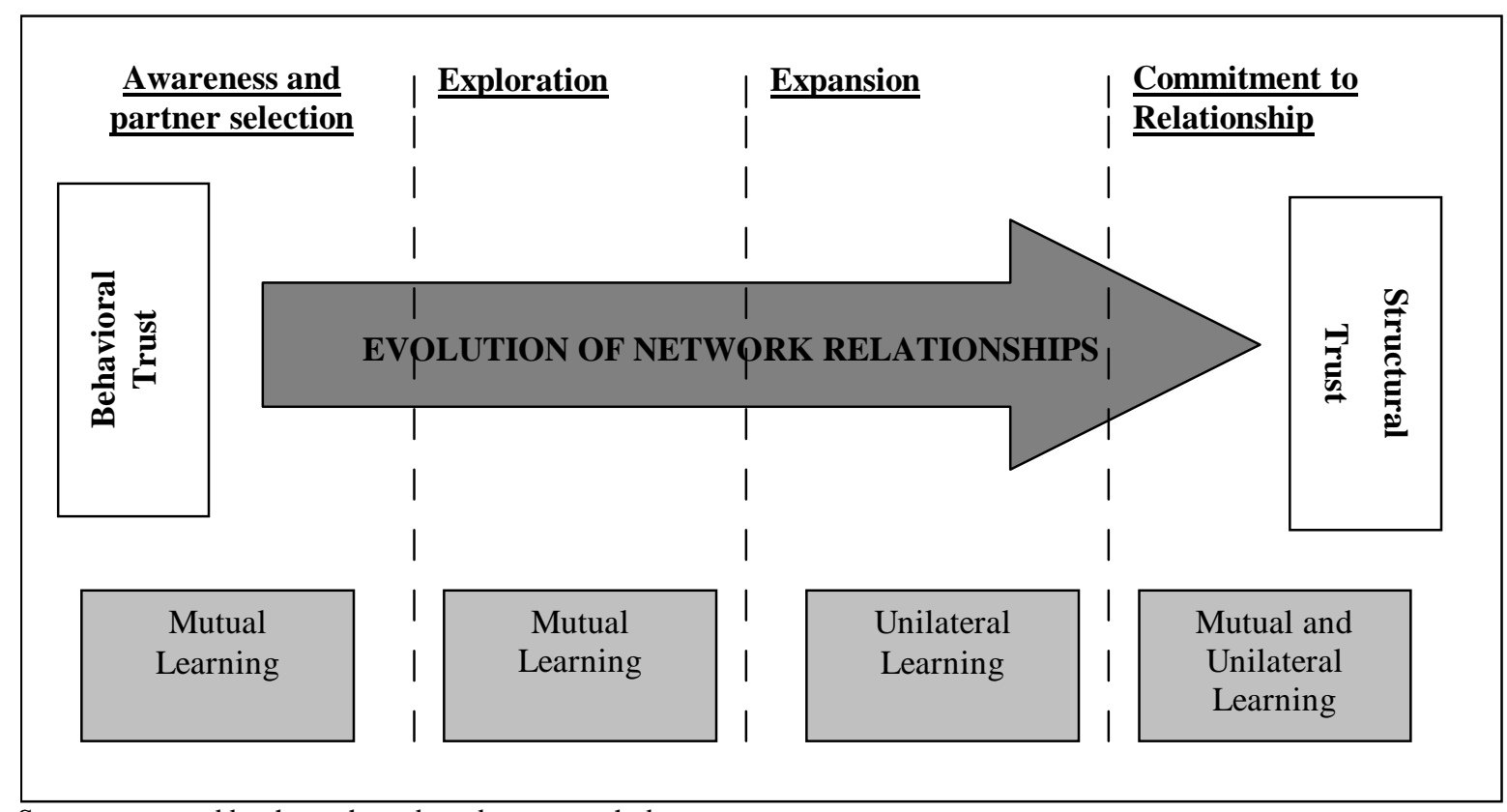

Source: prepared by the authors, based on research data.

By establishing a relationship between the evolutionary phases of interorganizational relationships, type of learning and trust, we can see that in the initial phases of formation, there was a predominance of behavioral trust elements in the relationships established. With the evolution of the relationships, we perceived, based on the managers' opinions, a strong presence of structural trust elements, mainly because of individualistic attitudes and opportunistic initiatives by the actors involved in the cooperative relationships. The evidence presented in this study enables new research questions involving the relationships among the studied constructs and requires new views of the involved elements since, theoretically, there is a tendency to evolve from unilateral learning to mutual learning and from structural trust to behavioral trust.

\section{FINAL CONSIDERATIONS}

This work was inspired by the studies developed by Karthik (2002) and was applied to the context of horizontal interorganizational relationships. The main goal was to understand how the learning process occurs in organizations inserted in networks from the perspective of the evolution of relationships over time. With the development of this research, a certain paradox was demonstrated, since there was evidence for a predominance of unilateral learning over mutual learning and a change from behavioral trust relations in the initial stages to structural trust relations in the advanced stages of relationship development. These results could be explained by the Brazilian culture or by specificities of the business sector studied (supermarkets). Opportunistic behavior is stimulated in this kind of business sector, in which there are some very large companies.

In contrast with Karthik's (2002) proposal, which was focused on strategic alliances, this study involved horizontal network relationships and revealed that processes of mutual learning emerged in the stage of awareness and partner selection, manifested by needs for greater socialization, information exchange and mutual investments by the organizations that opted to participate in the investigated network. Elements of mutual learning were also identified in the exploration phase and were revealed through the systematic efforts made by the partner organizations in the acquisition of abilities to 
enhance their absorptive capacity (Cohen \& Levithal, 1990). In the expansion phase, however, a predominance of unilateral learning was found, manifested by some of the partners' adoption of opportunistic initiatives resulting in contractual breaches or alterations with the objective of benefiting some of the organizations involved in the cooperative relationship. In the commitment phase, elements of mutual and unilateral learning were identified.

It is important to note that one of the limitations of this study is the use of the case study method, which makes generalization impossible; therefore, transferring the results to other contexts is also not possible. However, as we have pointed out (Eisenhardt \& Graebner, 2007; Siggelkow, 2007), this case can serve as an illustration and an inspiration for the field.

This study contributes to a better understanding of how the learning process occurs in horizontal interorganizational network relationships from an evolutionary perspective. It also signals the necessity for organizations involved in networks to invest in the development of mutual learning elements to guarantee the long-term sustainability of the relationships. Furthermore, this study has also made contributions by raising new questions that may lead to the development of future studies aimed at gaining a better understanding of learning priorities in interorganizational relationships. Furthermore, this research could be amplified by using other sources of evidence, such as the perceptions of organizations involved in other segments, to widen the applicability of the theoretical constructs used in this research as well as to carry out comparative research involving organizations from multiple networks. This research also opens up the possibility of new areas of investigation, since it develops a joint analysis of the themes of learning, trust and opportunism in cooperative relations.

\section{REFERENCES}

Antonacopoulou, E. (1999). Developing learning managers within learning organizations: the case of three major retail banks. In M. Easterby-Smith, L. Araujo, \& J. Burgoyne (Eds.). Organizational learning and the learning organization - developments in theory and practice. London: Sage.

Argyris C., \& Schön, D. (1998). Organizational learning. Reading, MA.: Addison-Wesley.

Child, J. (1999). Confiança e alianças internacionais: o caso das joint ventures sino-estrangeiras. In S. B. Rodrigues (Org). Competitividade, Alianças estratégicas e gerência internacional. São Paulo: Atlas.

Child, J., \& Faulkner, D. (1998). Strategies of co-operation: managing alliances, network, and joint ventures. Oxford: Oxford University Press.

Cohen, W., \& Levinthal, D. A. (1990). Absorptive capacity: a new perspective on learning and innovation. Administrative Science Quarterly, 35(1), 128-152.

Doz, Y. L., \& Hamel, G. (1998). Alliance advantage: the art of creating value through partnering. Massachusetts: Harvard Business Scholl Press.

Easterby-Smith, M., Araujo, L., \& Burgoyne, J. (Eds.) (1999). Organizational learning and the learning organization - developments in theory and practice. London: Sage.

Eisenhardt, K. M., \& Graebner, M. E. (2007). Theory building from cases: opportunities and challenges. Academy of Management Journal, 50(1), 25-32.

Fiol, C. M., \& Lyles, M. A. (1985). Organizational learning. Academy of Management Review, 10(4), 803-813. 
Inkpen, A. (2000). Learning through joint ventures: a framework of knowledge acquisition. Journal of Management Studies, 37(7), 1019-1043.

Karthik, N. S. I. (2002). Learning in strategic alliances: an evolutionary perspective. Academy of Marketing Science Review, 6(5 (inside pdf file10)), 1-14.

Knight, L. (2002). Network learning: exploring learning by interorganizational networks. Human Relations, 55(4), 427-454.

Lane, P. J., Salk, J. E., \& Lyles, M. (2001). Absorptive capacity, learning and performance in international joint venture. Strategic Management Journal, 22(12), 1139-1161.

Larsson, R., Bengtsson, L., Henriksson, K., Sparks, J. (1998). The interorganizational learning dilemma: collective knowledge development in strategic alliances. Organization Science, 9(3), 285-305.

Pereira, B. A. D. (2005). Estruturação de relacionamentos horizontais em redes. Tese de doutorado. Universidade Federal do Rio Grande do Sul, Porto Alegre, RS, Brasil.

Prange, C. (1999). Organizational learning - desperately seeking theory? In M. Easterby-Smith, L. Araujo, \& J. Burgoyne (Eds.). Organizational learning and the learning organization developments in theory and practice. London: Sage.

Senge, P. (1990). The fifth discipline: the art and practice of the learning organization. New York: Doubleday Currency.

Siggelkow, N. (2007). Persuasion with case studies. Academy of Management Journal, 50(1), 20-24.

Sweringa, J., \& Wierdsma, A. (1995). La organización que aprende. Wilmington, USA: AddisonWesley.

Yin, R. (2002). Case study research (3rd ed.). Thousand Oaks, CA: Sage Publications. 